Yuri Safonov, Doctor of Economics, Professor, Professor of the Department of macroeconomics and public administration, State university Kyiv National Economic University named Vadym Hetman (Kyiv, Ukraine);

Evgeny Maslennikov, Doctor of Economics, Associate Professor, Professor of the Department of Economics and Management, Odessa National University by I.I. Mechnikov (Odessa, Ukraine);

Natalia Selivanova,

Candidate of Economic Sciences, Associate Professor of the Department of Accounting, Analysis and Audit, Odessa National Polytechnic University (Odessa, Ukraine)

\title{
METHODICAL PRINCIPLES OF DEFINITION OF ECONOMIC ENTITY'S COMPETENCE TO FORMING OF INNOVATIVE-INVESTMENT INDUSTRY CLUSTERS
}

In the article the essence of economic entity's competencies, the importance of creating innovation-investment clusters, methodology and sequence of determination of economic entity's key competencies to create innovativeinvestment clusters are considered. The study demonstrated that the identification and assessment of an entity of its core competencies in the formation of innovation and investment cluster allows just choose activities in this cluster that will bring the greatest financial result and effect.

Keywords: ompetences, chain of values, cluster, added value, competitive advantage, innovation cluster.

DOI: 10.21272/mmi.2017.4-25

Formulation of the problem. Today the most effective form of innovative processes organization is clustering in the region that in the market operate not only single enterprises but entire complexes and associations, which because of this reduces its spending activity. These associations help to increase productivity, accelerate innovation in production; can also contribute to improving the competitiveness of the economy, without requiring significant funds. Association into the cluster enables to create a specific economic space, whereby the expansion of exports, expanding free trade cluster, the free movement of human resources and capital.

Analysis of recent researches and publications. The study of the issues of clustering, identifying the key competencies for its forming is reflected in the writings of scientist such as M. Porter [1], A. Brouwer et al [2], A. Shastitko [3], G. Hamell, K. Prahalad [4]. An important contribution to the theory and practice of formation of the cluster model was made by Ukrainian scientists S. Sokolenko [5], N. Voinarenko [6], V. Zakharchenko [7]. Innovative clusters can act as institutional mechanisms for the implementation of the relevant innovative solutions. Also the methodology for determining competencies for the formation of innovation clusters in domestic literature is not enough.

The aim of the article is to determine the methodical basis for the definition of competences of business entities for the formation of innovation-investment clusters.

The main results of the study. The official definition of the innovative cluster first appeared in 2000 in the framework of the International conference by innovation policy and technology.

The classical definition of a cluster is definition of $\mathrm{M}$. Porter, who was considered a cluster as "geographically concentrated groups of interconnected companies, specialized service providers, firms in related industries and associated organizations (for example, universities, standards agencies, trade associations) in particular fields that compete but at the same time and work together» [1].

The creation of a cluster in the regional economy to ensure concentration of production and sales of finished products, cooperation efforts over the dissemination of innovative processes, providing for competition, communication processes within the cluster forming and joint coordination of activities. 
In addition, territorial production clusters should support small and medium business. That is why traditional approaches to the development of small and medium business it is necessary to include regional, based on the creation of innovative-investment clusters.

The competence of the enterprises united into a cluster, giving the possibility to correctly solve tasks, to successfully operate on the basis of practical experience. These factors combine to increase the region's competitiveness, creating new conditions and requirements for doing business.

State support has influent into the initial development of the cluster as it creates the preconditions for the combination of national vision, economic development strategy and regional capacity, which may affect the actual development.

The directions of the state regional cluster policy include:

- study of the development of economic clusters at the regional level, namely monitoring of the structure of the cluster, the territory of its separate parts, financing analytical studies of the prospects of cluster development on foreign markets, evaluation of the influence of the cluster on the region and the socio-economic sphere;

- creation of communication links for potential participants of innovative clusters due to its occurrence in the process of development and consideration of regional development strategies, promoting the exchange of experience between regions on the establishment of cluster policy;

- promoting the inclusion of members of the cluster programs promoting its access to foreign markets, implementation of joint marketing and advertising research, facilitate networking opportunities and bring together educational institutions and enterprises;

- development of communication-information infrastructure;

- formation of the institutional environment for the development of economic clusters.

It should highlight the features of of innovation-investment clusters, which allow determining the system of its essential characteristics:

1. Innovative-investment cluster acts as a super-system because it involves different types of clusters that are created through innovation that involve the formation and dissemination in the environment.

2. Through innovation, the participants in this cluster present the results in the form of innovation not only in production but also in management, social work, organization and some like this.

3. The participants of the innovative cluster are different companies that are linked by a single development strategy and the innovation process, but each of them performs its functions.

4. To create an innovation cluster must have certain competencies, technical capabilities, logistic communication channels, relations with the aim of ongoing innovative development.

5. On the basis of a competition to build relationships between participants that leads to successful collaboration and provides the ability to use the key competencies to achieve high results.

The processes of clusters formation in the national economy are characterized by a low effectiveness of the established structures and the lack of such an environment that will encourage the formation of innovative-investment clusters.

The main reasons for the poor distribution of such processes in Ukraine, we consider:

- ineffective government control of innovative-investment activity through a system of financial and economic policy;

- randomness in adoption of legal acts related to innovation and investment activity in the national economy;

- lack of state support of innovative and investment activity of economic entities in the national economy;

- lack of legal support processes of clustering;

- weak innovation and investment activity of industrial enterprises;

- ongoing transformation processes in the national economy;

- political upheavals during the 2013-2016 period;

- chaotic processes in the banking sphere; 
- the global financial crisis in the national economy.

For Ukraine the clusters' associations are organizational and economic innovation, however, there are more than 20 clusters (some clusters of Ukraine are shown in table 1), but they are all created without the support at national and regional level.

Table 1- Cluster association of Ukraine [8; 9]

\begin{tabular}{|c|c|c|}
\hline Region & Period & Clusters \\
\hline $\begin{array}{l}\text { Podillya, } \\
\text { Khmelnitsk, } \\
\text { Vinnytsia, } \\
\text { Ternopil }\end{array}$ & Since 2005 & $\begin{array}{l}\text { - new building materials; } \\
\text { - the protection and commercialization of cultural heritage; } \\
\text { - information and educational spheres; } \\
\text { - cluster of organic farming; } \\
\text { - fruit cluster "Podolsky Apple" }\end{array}$ \\
\hline Prikarpattya & Since 2000 & $\begin{array}{l}\text { - tourism; } \\
\text { - production of souvenir products; } \\
\text { - manufacture of articles of fur; } \\
\text { - woodworking; } \\
\text { - construction and building materials; } \\
\text { - processing of herbs; } \\
\text { - conservation and protection of mountain rivers; } \\
\text { - historical and cultural heritage; } \\
\text { - sewing; } \\
\text { - fur; } \\
\text { - food; } \\
\text {-medicine and therapeutic; } \\
\text { - recreation and tourism }\end{array}$ \\
\hline Rivno & Since 2000 & - woodworking Rocketmusic district \\
\hline Odessa & Since 2007 & $\begin{array}{l}\text { Production and processing of agricultural products } \\
\text { Under development - cluster winemaking }\end{array}$ \\
\hline
\end{tabular}

As defined in the study, a significant competence of the entities are knowledge, skills, technologies, models, methodology and so on, which are the main instrument in the formation of innovative-investment activity of industrial clusters for the purpose of strategic development entities and long-term competitive advantage.

According to the Strategy of sustainable development «Ukraine - 2020» [10], the introduction in Ukraine of European living standards and Ukraine's withdrawal to the leading position in the world will be by vector of development, to ensure sustainable development of the state, structural reform, higher standards of living. Ukraine should become a state with a strong economy and innovations. Proposed strategic framework confirms the need of formation of innovative-investment activity of industrial clusters, both at the national level and the regional one.

Innovative-investment activity of industrial clusters is an association of business entities that create and innovate. It should be noted that statistics of innovation explores innovation activity of economic entities two aspects: innovation activity and innovation.

Innovative-investment development of industrial clusters effective complex uses all its components. The basis of formation of innovative-investment activity of industrial clusters must be industrial businesses that are innovation-active and innovate. In table 2 the study of innovative activity and implementation of innovations at industrial enterprises in the period 2000-2015 is done. It should be noted that the decline in investment activity observed in recent years, is connected with the reduction of innovative activity of economic entities.

Analytical parameters in the table 2 suggest that the number of enterprises that creates innovations and implementing them differ. This suggests that not all innovations come to life. However, the availability of longterm strategic formation of innovative-investment activity of industrial clusters shows the analytical dynamics of creation and introduction of innovations in industry of the national economy (Fig. 3). 
Ю.М. Сафонов, Є.І.Масленніков, Н.М. Селіванова. Методичні засади визначення компетенцій суб'єктів господарювання для формування інноваційно-інвестиційних промислових кластеріві

Table 2 - Dynamics of innovative activity and implementation of innovations at industrial enterprises of Ukraine for $\mathbf{2 0 0 0 - 2 0 1 5}$ (authors based on information of the [11])

\begin{tabular}{|c|c|c|c|c|}
\hline Years & $\begin{array}{c}\text { The share of } \\
\text { companies, creating } \\
\text { innovation, } \%\end{array}$ & $\begin{array}{c}\text { The share of companies } \\
\text { that introduced } \\
\text { innovations, } \%\end{array}$ & $\begin{array}{c}\text { Dynamics of indicators } \\
\text { of companies created } \\
\text { innovation, \% }\end{array}$ & $\begin{array}{c}\text { Dynamics of indicators of } \\
\text { the companies that } \\
\text { introduced innovations, \% }\end{array}$ \\
\hline 1 & 2 & 3 & 4 & 5 \\
\hline 2000 & 18,0 & 14,8 & 100,0 & 100,0 \\
\hline 2001 & 16,5 & 14,3 & 91,7 & 96,6 \\
\hline 2002 & 18,0 & 14,6 & 109,1 & 102,1 \\
\hline 2003 & 15,1 & 11,5 & 83,9 & 87,8 \\
\hline 2004 & 13,7 & 10,0 & 90,7 & 82,0 \\
\hline 2005 & 11,9 & 8,2 & 86,9 & 122,0 \\
\hline 2006 & 11,2 & 10,0 & 94,1 & 115,0 \\
\hline 2007 & 14,2 & 11,5 & 126,8 & 93,9 \\
\hline 2008 & 13,0 & 10,8 & 91,6 & 99,1 \\
\hline 2009 & 12,8 & 10,7 & 98,5 & 107,5 \\
\hline 2010 & 13,8 & 11,5 & 107,8 & 111,3 \\
\hline 2011 & 16,2 & 12,8 & 117,4 & 106,3 \\
\hline 2012 & 17,4 & 13,6 & 107,4 & 100,0 \\
\hline 2013 & 16,8 & 13,6 & 96,6 & 89,0 \\
\hline 2014 & 16,1 & 12,1 & 95,8 & 98,3 \\
\hline 2015 & 16,3 & 11,9 & 101,2 & \\
\hline
\end{tabular}

So, in 2015 , created an innovation for $16.3 \%$ of enterprises introduced innovations only about three quarters of industrial enterprises or $11.9 \%$, which are innovation-active.

Key categories for statistical studies of innovation - active innovative enterprise, innovative enterprise, innovation activity, introduction of innovations, for use in a cluster approach would require methodological support, which is an element for further research.

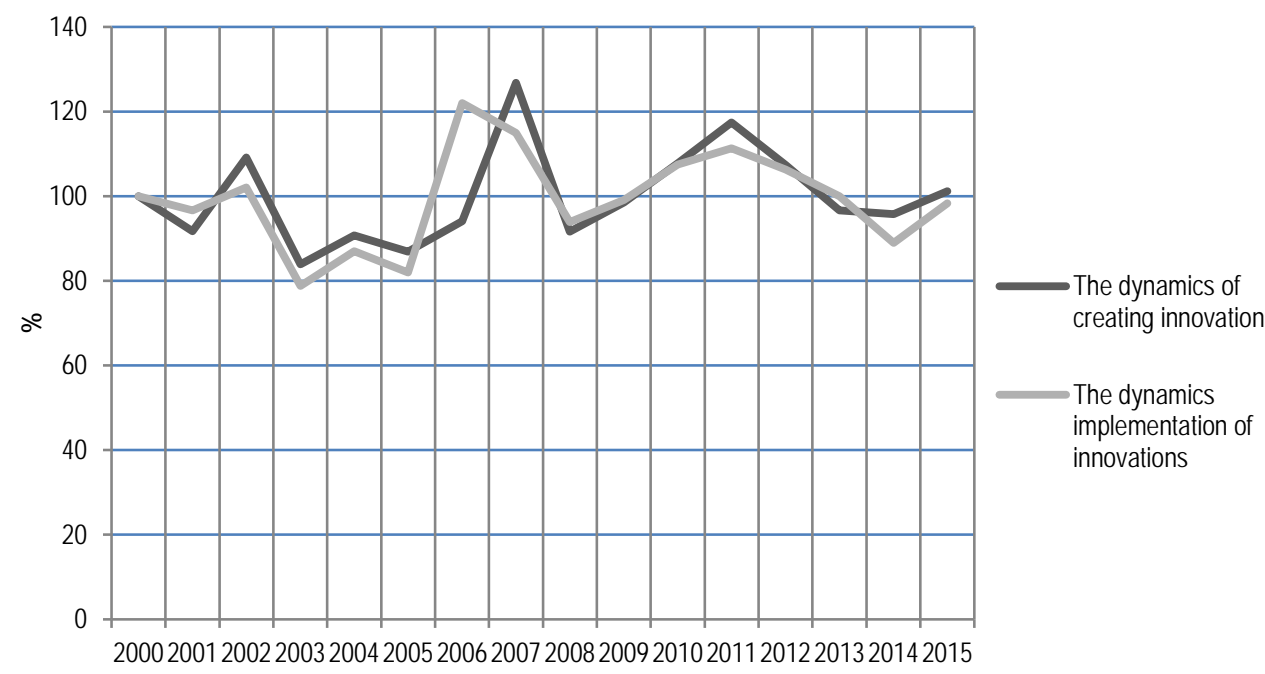

Figure 1 - Dynamics of the creation and implementation of innovations in industry of the national economy (authors' development) 
The establishment of the business relationships that are based on a desire to satisfy the needs of consumer products is the task of the innovation cluster. That is why different entities based on commercial interests, competition and the possible options of reducing expenditure, unite business relationships in the chain of added value creation.

Thus, an effective policy of modernization of the region must have as a basis the circuit of value creation that already exist or emerging in the region.

In today's world practice there is the concept of creating a value added product, which was introduced by M. Porter [1]. It is widely used for the formation of the development strategy. The essence of this concept is that each sector in the national economy is considered as a chain of industries that consistently add value to end product consumption.

Classic chain of added value formation consists of seven major economic activities conducted by enterprises in various areas of functioning. They include: research, development, supply, production, marketing, sale and service. Each individual function can create value has a unique set of factors that determine the differences in costs for these activities. Thus, each organization has its own individual sources of competitive advantage [12].

The key success factors that form the profitability of entities and increase of its capitalization, determine the requirements for circuit values. Such factors include: quality, time, cost reduction, customer service and performance of the product.

For the company better focus its resources in one particular chain link, in which you can achieve some significant advantages and provide the greatest financial return, through the use of its core competencies. When a business entity is a basic unit with high added value, it has the ability to influence partners and to submit own price terms.

The development of the concept of value chain products has provided an opportunity for many business entities to determine own core competencies, focus on them all own resources and to refuse to perform those functions that require large expenditures of time, labor and money than is spent on specialized only on these processes, subjects.

The key competence of the company (KCC) is a unique and difficult reproducible knowledge, skills, technology, know-how and the like, which are formed on the basis of experience of the operation of the company and provide the company a sustainable and long term competitive advantages through the creation of additional consumer value of the product [13].

Core competencies provide access to a wide range of markets; create additional consumer value of the product (it is CCP creates the most value, which takes the consumer); provide a synergistic effect. They also have features such as uniqueness, complexity, durability and abrasion resistance, originality, indispensability, possibility of improvement and a focus on the consumer.

In modern economic literature there are two main approaches to the definition and analysis of the core competencies of the company.

In accordance with the first approach, media competence is individuals, individuals that carry out a particular work activity; it analyzes the intangible assets of the enterprise [14]. Competence mapping is done through interviews, psychological tests, interviews and the like. The disadvantage of this approach is the excessive concentration on business and personal qualities of employees and subjectivism, however, the core competencies of a business entity is a broader concept.

According to the second approach, competence assessment is based on an analysis of all assets that can be the source of competence. Methods of assessing key competences by Efremov V. S. and I. A. Hanikov are widespread [15], according to which assessment and analysis of market and internal business environment, core competence is defined and developed a strategic plan. The advantages of this method are the logical structures of analysis, clarity and accessibility of explanations of individual stages of assessment of key competencies based on the proportion of use-value. The disadvantages are the 
Ю.М. Сафонов, Є.І. Масленніков, Н.М. Селіванова. Методичні засади визначення компетенцій суб'єктів господарювання для формування інноваційно-інвестиційних промислових кластеріві

complexity and subjectivity in the formation of the matrix and weak (not two way) relationship between core competence and strategy of the enterprise [16].

First, the company has a number of internal and external competencies and decides about the implementation of the diversification program for the formation of innovation cluster.

Internal competencies include:

- innovative technologies;

- innovative processes in business;

- innovation management;

- internal competitiveness;

- innovative labor potential.

External competencies include:

- the relationship with contractors;

- financial and investment support;

- political support;

- innovative security on the macro level.

We can offer the following methods of determining core competencies of business entities.

The first step is defining and identifying: a study of the status and structure of resource provision of the entity, determine the sources of competitive advantages. The result of this step is possible competence of a business entity. A study of the competencies of a business entity, necessary for the formation of the cluster study projects that the entity is already implementing.

The next step is to determine which tangible and intangible resources, i.e. competence, used business entity for the implementation of implemented business projects.

The following structure of the value of finished products, goods, works and services the entity provides an opportunity to understand what the internal components and in what proportions the property consists of the final product, what abilities, resources and competences were involved in the production of these components. This will help to more accurately focus the activities of the strategic plan the activities of the entity. Properties of finished products, goods, works and services are distributed according to the degree of importance using the method of pairwise comparisons.

Next, it is determined if the kinds of assets owned by the units of the entity. This is necessary in order to identify key competences of the individual parts of the enterprise, uncover additional skills and capabilities that exist in the structural segments of the enterprise. That is why the ability defines all resources that belong to the business entity.

So, on this stage of the study it can be concluded about the essential competencies of the entity, given that each property of the finished products, which is part of the structure of consumer value, has a different weight for consumers on the market.

After the stage of definition and identification of core competencies and assessment of what resources the business entity achieves success in the implementation of projects and their dynamics, we investigate the potential of this enterprise. It appears that, as you can use your own capital to innovative cluster formation, taking into account the selected key competences.

You need to search for strategic matches between activities (operating, financial, investment) enterprises that are already underway, and new, limited and guided by the activity of the cluster. The definition of such mappings is possible in the following areas:

- market (type of customer, distribution channels, service, brand, advertising companies);

- production (total production capacity, technology, competitors);

- management (structure and management system, the knowledge and experience of management personnel).

The next step is to create a model of the internal structure of relationships and dependencies between 
existing resources and potential capabilities and competencies possessed by the economic entity. Naturally, this takes into account not only the current level of resources, but the resources necessary for the further activity of the enterprise considering entering into an innovative cluster.

As a result of this system of research competencies, the entity has an idea of what projects it can realize in the modern market conditions and the development of what competences needed to implement the strategy of diversifying an active entity on a segment component.

At this stage you need to select the business projects under the program of diversification of resources that meet the requirements to key competences of a business entity.

Based on the analytical information research, the formation of the strategic plan is based on the rule of reverse logic is defined by the carriers of core competencies, identified by capabilities (businessprocesses) and the resources they control, and further development of the business is built to support and development of these and directly related elements of the segmental system of the entity.

Given the above, we can conclude: the basis of competition of economic entities not acting as endfinished products, which is the result of production and are a key competence that is the core of enterprise activity.

Thus, the entities that are positioning to market only its finished products, often do not take into account the possibility of obtaining additional financial result from the existing key competences and opportunities for developing a network of relations between economic entities on the production of finished products, goods, works and services. Many domestic enterprises form a self-contained business process, creating a vertically integrated company, resulting in erosion of financial resources and long period of formation of key competencies.

Conclusions. Identification and assessment by the entity of its core competence in the formation of innovative-investment cluster allows you to accurately choose activities in this cluster that will yield the greatest financial results and impact. Competencies help to maintain the planned behavior of the entity when entering the innovation cluster.

Each participant of the of innovation-investment clusters may be a specific competence, despite the fact that they use it as a competitive advantage or not, but the lack of key competencies leads to a rapid displacement of the holder from the cluster. Core competence enables long-term operations of a business entity and effective activity in the cluster using the uniqueness and diversity of its activities. Also competence is a source of creating competitive advantages of the subject in the formation of innovativeinvestment clusters.

The study demonstrated that the identification and assessment of an entity of its core competencies in the formation of innovation and investment cluster allows just choose activities in this cluster that will bring the greatest financial result and effect. Competencies help maintain the intended behavior of the entity from entry into innovation cluster. Each participant innovative cluster may be some competence, even though they use it as a competitive advantage or not, but lack key competencies leads to the rapid displacement of the entity from the cluster. The technique of identifying key competencies will help create innovation and investment industrial cluster in terms of European integration and enhanced competitiveness.

To help identify the most important key competence, it is necessary to take into account their most important characteristics, namely universality, the complexity of copying by competitors and providing a competitive advantage.

Further research will be aimed at forming system of definition of economic entity's competence to forming of innovation-investment industry clusters.

1. Портер М. Конкуренция / М.Портер; [пер. с англ.] - М: Издательский дом «Вильямс». 2005. - 608 с.

2. Брувер А. Стратегічне планування місцевого розвитку: розробка та впровадження проектів: Навч. посіб. / А. Брувер, 
Ю.М. Сафонов, Є.І. Масленніков, Н.М. Селіванова. Методичні засади визначення компетенцій суб'єктів господарювання для формування інноваційно-інвестиційних промислових кластеріві

Н. Руденко, С. Грищенко. - К.: Європ. комісія, 2006. - 168 с

3. Шаститко А.Е. Кластеры как форма пространственной организации экономической деятельности: теорія вопроса и эмпирические наблюдения / А.Е. Шаститко // Теория экономических исследований. - 2009. - № 2 - Режим доступа к журналу: http://cyberleninka.ru.

4. Хэмел Г. Конкурируя за будущее / Г. Хэмел, К.К. Прахалад. - М.: ЗАО «Олимп-Бизнес», 2002. - 288 с.

5. Соколенко С.. Кластери в глобальній економіці / С.І. Соколенко. - К. : Логос, 2004. - 848 с.

6. Войнаренко М.П. Кластери в інституційній економіці: монографія / М.П. Войнаренко. - Хмельницький: ХНУ, ТОВ «Тріада-М», 2011. - 502 c.

7. Захарченко В.И. Инновационный менеджмент: теория и практика в условиях трансформационной экономики / В.И. Захарченко, Н.Н. Меркулов, Н.Н. Корсикова. - К.: ЦУЛ, 2012. - 448 с.

8. Колодинский С.Б. Рационализация кластерных структур инновационного развития региона / Материалы IX Международной научно-практической конференции "Актуальные вопросы инновационной деятельности", Симферополь, 2014. - C. $68-71$.

9. Соколенко С.И. Производственные системы глобализации: сети, альянсы, партнерства, кластеры. - К.: Колос, 2013. $-546 \mathrm{c}$.

10. Указ Президента України «Стратегія сталого розвитку «Україна - 2020» від 12 січня 2015 року № 5/2015 [Електронний ресурс] // Адміністрація Президента України. - Режим доступу: http://zakon4.rada.gov.ua/laws/show/5/2015.

11. Наука, технології та інновації II Державна служба статистики України [Електронний ресурс]. - Режим доступу: http://www.ukrstat.gov.ua.

12. Уварова А.Я. Формирование цепочек добавленной стоимости экспортноориентированной продукции / А.Я. Уварова, О.В. Стрелкова // Вестник ОрелГИЭТ. - 2011. - №2(16). - С. 5-11.

13. Суханюк Ю. Ключові компетенції підприємства: сутність та оцінювання [Електронний ресурс] / Ю. Суханюк, С. Яковенко. - Режим доступу: http://ukr.coolreferat.com.ua/nuda/klyuchovi-kompetenciyi-pidpriyemstva-sutniste-taocinyuvannya/main.html.

14. Верба В.А. Проблеми ідентифікації компетенцій підприємства [Електронний ресурс] /В.А. Верба, О.М. Гребешкова - Режим доступу: http://www.management.com.ua/strategy/str100.html.

15. Ефремов В.С. Ключевая компетенція организации как объект стратегического анализа [Електронний ресурс] / В.С. Ефремов, И.А. Ханыков. - Режим доступу: http://www.mevriz.ru/articles/2002/2/1014.html.

16. Побережець О.В. Информационно-технологический фактор в развитии бизнеса / О.В. Побережець // Ринкова економіка: сучасна теорія і практика управління. Збірник наук.праць. - Вип. 15, т. 10. - Одеса: ОНУ. - 2007. - С. 163-170.

1. Porter, M. (2005). Konkurentsiya [Competition]. M: Izdatelskiy dom «Vilyams» [in Russian].

2. Bruver, A., Rudenko N., \& Hryshchenko, S. (2006). Stratehichne planuvannya mistsevoho rozvytku: rozrobka ta vprovadzhennya proektiv [Strategic planning for local development: development and implementation]. K.: Yevrop. komisiya [in Ukrainian].

3. Shastitko, A.Ye. (2009). Klastery kak forma prostranstvennoy organizatsii ekonomicheskoy deyatel'nosti: teoríya voprosa i empiricheskiye nablyudeniya [Clusters as a form of spatial organization of economic activities: teoriya issue and empirical observations]. Teoriya ekonomicheskikh issledovaniy - Theory of Economic Research, 2. Retrieved from http://cyberleninka.ru [in Russian].

4. Khemel, G., \& Prakhalad, K.K. (2002). Konkuriruya za budushcheye [Competing for the Future]. M.: ZAO «Olimp-Biznes» [in Russian].

5. Sokolenko, S.I. (2004). Klastery v hlobalniy ekonomitsi [Clusters in the Global Economy]. K.: Lohos [in Ukrainian].

6. Voynarenko, M.P. (2011). Klastery v instytutsiyniy ekonomitsi: monohrafiya [Clusters institutional economics: monograph] Khmelnytskyy: KHNU, TOV «Triada-M» [in Ukrainian].

7. Zakharchenko, V.I., Merkulov, N.N., \& Korsikova, N.N. (2012). Innovatsionnyy menedzhment: teoriya i praktika v usloviyakh transformatsionnoy ekonomiki [Innovation Management: Theory and Practice in the conditions of transformation economy]. K.: TSUL [in Russian].

8. Kolodinskiy, S.B. (2014). Ratsionalizatsiya klasternykh struktur innovatsionnogo razvitiya regiona [Rationalization of cluster structures of Regional Development]. Materialy IX Mezhdunarodnoy nauchno-prakticheskoy konferentsii «Aktualnyye voprosy innovatsionnoy deyatelnosti» - Proceedings of the IX International scientific-practical conference «Actual problems of innovative activity» (pp. 68-71). Simferopol [in Russian]

9. Sokolenko, S.I. (2013). Proizvodstvennyye sistemy globalizatsii: seti, alyansy, partnerstva, klastery [The production system of globalization: Networks, alliances, partnerships, clusters]. K.: Kolos [in Russian].

10. Administratsiia Prezydenta Ukrayiny - Administration of President of Ukraine (2015). Ukaz Prezydenta Ukrayiny «Stratehiya staloho rozvytku «Ukrayina - 2020» vid 12 sichnya 2015 roku № 5/2015 [President of Ukraine «Sustainable Development Strategy» Ukraine - 2020» from January 12, 2015 number 5/2015]. zakon4.rada.gov.ua. Retrieved from http://zakon4.rada.gov.ua/laws/show/5/2015 [in Ukrainian].

11. State Statistics Service of Ukraine (n.d.). Nauka, tekhnolohiyi ta innovatsiyi [Science, technology and innovation.] ukrstat.gov.ua. Retrieved from http://www.ukrstat.gov.ua [in Ukrainian]. 
12. Uvarova, A.Ya., \& Strelkova, O.V. (2011). Formirovaniye tsepochek dobavlennoy stoimosti eksportnooriyentirovannoy produktsii [Formation of value-added export-oriented production chains]. Vestnik OrelGIET, 2(16), 5-11 [in Russian].

13. Sukhanyuk, Yu., \& Yakovenko, S. (n.d.). Klyuchovi kompetentsiyi pidpryyemstva: sutnist ta otsinyuvannya [The key competence of the company: the nature and evaluation]. ukr.coolreferat.com.ua. Retrieved from http://ukr.coolreferat.com.ua/nuda/klyuchovi-kompetenciyi-pidpriyemstva-sutniste-ta-ocinyuvannya/main.html [in Ukrainian].

14. Verba, V.A., \& Hrebeshkova, O.M. (n.d.). Problemy identyfikatsiyi kompetentsiy pidpryyemstva [Problems identifying competencies enterprises]. management.com.ua. Retrieved from http://www.management.com.ua/strategy/str100.html [in Ukrainian].

15. Yefremov, V.S., \& Khanykov, I.A. (2002). Klyuchevaya kompetentsiya organizatsii kak obyekt strategicheskogo analiza [The key competence of the organization as an object of strategic analysis]. mevriz.ru. Retrieved from http://www.mevriz.ru/articles/2002/2/1014.html [in Russian].

16. Poberezhets, O.V. (2007). Informatsionno-tekhnologicheskiy faktor v razvitii biznesa [Information and technological factor in business development]. Rynkova ekonomika: suchasna teoriya i praktyka upravlinnya. - Market economy: contemporary theory and practice of management, 15 (10), 163-170. Odesa: ONU [in Russian].

Ю.М. Сафонов, д-р екон. наук, професор, профессор кафедри макроекономіки та державного управління, Державний вищий навчальний заклад «Київський національний економічний університет імені Вадима Гетьмана» (м. Київ, Україна);

€.I. Масленніков, д-р екон. наук, доцент, професор кафедри економіки та управління, Одеський національний університет імені І.І. Мечникова (м. Одеса, Україна);

H.M. Селіванова, канд. екон. наук, доцент кафедри обліку, аналізу та аудиту, Одеський національний політехнічний університет (м. Одеса, Україна)

Методичні засади визначення компетенцій суб'єктів господарювання для формування інноваційноінвестиційних промислових кластерів

У статті розелянуто сутність компетенцій суб'єктів господарювання, важливість створення інноваційноінвестиційних кластерів, методологія і послідовність визначення ключових компетенцій підприємств для формування інноваційно-інвестиційних кластерів. У дослідженні доведено, що ідентифікація та оцінка суб'єктом господарювання своїх ключових компетенцій при формуванні інноваційно-інвестиційного кластеру надає змогу точно вибрати напрямки діяльності в такому кластері, які принесуть найбільший фінансовий результат і ефрект.

Ключові слова: компетенції, ланцюг цінностей, кластер, додана вартість, конкурентна перевага, інноваційний кластер.

Ю.Н. Сафонов, д-р экон. наук, профрессор, профессор кафедры макроэкономики и государственного управления, Государственное высшее учебное заведение «Киевский национальный экономический университет имени Вадима Гетьмана» (г. Киев, Украина);

Е.И. Масленников, д-р экон. наук, доцент, профессор кафедры экономики и управления, Одесский национальный университет имени И.И. Мечникова (г. Одесса, Украина);

Н.Н. Селиванова, канд. экон. наук, доцент кафедры учета, анализа и аудита, Одесский национальный политехнический университет (г. Одесса, Украина)

Методичесике основы определения компетенций субъектов хозяйствования для формирования инновационно-инвестиционных промышленных кластеров

В статье рассмотрена сущность компетенций субъектов хозяйствования, важность создания инновационноинвестиционных кластеров, методология и последовательность определения ключевых компетенций предприятий для формирования инновационно-инвестиционных кластеров.

Ключевые слова: компетенции, цепь ценностей, кластер, добавленная стоимость, конкурентное преимущество, инновационный кластер.

Отримано 31.10.2016 p. 